\title{
Collecting Oral Histories for Entrepreneurship Research
}

Brian McKenzie

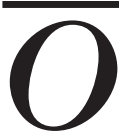

ral bistory collections can offer a wealth of detailed

information for entrepreneurship researchers. The

stories that entrepreneurs tell provide researchers with insight into both perspective and into substantive issues of entrepreneurial bebavior.

The life stories of entrepreneurs offer students of entrepreneurship insight into both the explicit and the tacit knowledge of working entrepreneurs.

Ethnography has been described as the inscription of social discourse (Geertz 1973, p.19) and is a tool of the qualitative research technique of participant-observation (Emerson et al. 1995, p.1). Oral history collection is a form of ethnography particularly suited to the study of entrepreneurship. The popular press is full of the biographies and histories of successful entrepreneurs (Barton 1998; Berlin 2005; Frolick 1999; Gates and Hemingway 1999; Kaplan 2000; Rothchild 1991 to name a few).The field of business management has a long history of utilizing storytelling in the form of case studies as a pedagogical tool (Alvarez and Merchan 1992, p.29) and more recently has begun to utilize case studies in research (Chetty 1996; Eisenhardt 1989; Kanter 1983).As a scholarly tool, oral history is an accurate collection of subjective evidence (Moss 1974, p.11) created by the memoirist (Moss and Mazikana 1986, p.25) in dialogue with the interviewer. Oral history documents contain the self-created life stories of memoirists. The life stories that entrepreneurs tell represent their attempts to make sense of the events of their past.

Alex Stewart has suggested that ethnography is well suited to the study of entrepreneurship and that participant observation holds the promise of allowing scholars a unique glimpse of entrepreneurship's crucial lore (Stewart 1991, pp. 77-78). Murray Low and Ian MacMillan indicated the need for more contextual and process oriented research in the field of entrepreneurship (Low and MacMillan 1988, p.156). Howard Aldrich and Ted Baker claim ethnographic methods may allow researchers to gain new insight from their field observations (Aldrich and Baker 1997, p.393). If new and promising research is to be conducted in the domain of entrepreneurship, it follows that fieldwork is one promising avenue that must be considered. Stewart has advanced the use of anthropological theory for the development of entrepreneurship research, saying: "Few business school scholars are trained in anthropology, but it is possible for them to borrow bundles of concepts from anthropology" (Stewart 2003, p.11).
Oral history interview collections can have many uses in entrepreneurship research. Steinar Kvale suggests two broad metaphors of the role of the researcher: as a miner and as a traveler (Kvale 1996). The researcher as miner seeks to unearth valuable material; the researcher as traveler hears and reports what he has heard. Oral history can be utilized by both of these metaphorical researchers in the field of entrepreneurship research. Researchers who use oral history collection to unearth valuable material can undertake theoretical studies, such as the author's dissertation (McKenzie 2003), or inquiries into the tacit knowledge of entrepreneurs, such as Chris Steyaert's investigation of the development of local knowledge of entrepreneurship (Steyaert 1995). Researchers who use oral history collection as a form of travel tend to undertake ethnographic studies such as David Boje's study of organization formation through the use of storytelling in an office supply firm (Boje 1991).

Ethnography in general, and the analysis of oral narrative in particular hold promise as being well suited to the study of entrepreneurship The balance of this article lays out methodological arguments designed to assist researchers in the use of oral history collection as a tool for research in entrepreneurship.

\section{Oral History Collection as a Research Tool}

Oral history collection is both a very old phenomenon and a very new one. David Henige traces the origins of oral history collection to Homer's 800 B.C. account of the fall of Troy (Henige 1982, p.7). Contemporary oral history collection is credited to Allan Nevins, who established the Columbia University "Great Man" recording project in 1948 (Evans 1987, p.34; Lummis 1987, p.17; Nevins 1996, p.33; Thompson 1988, p.58). While earlier collections had been undertaken by Lawrence Reddick and the Federal Writers Project (Starr 1996, p. 43), it was the development of portable tape recorders that led to acceptance of oral histories as a source of historical material and then to the recognition of oral histories as valuable data in their own right (Rosenberg 1978, p. xiv).

Oral history evidence, which is referred to as an actuality (Ridington 2001, p.1), has been defined as “... an account of firsthand experience recalled retrospectively, communicated to an interviewer for historical purposes and preserved on a system of reproducible sound" (Lummis 1987, p.27). As a scholarly tool, oral history interviews are an accurate collection of subjective evidence (Moss 1974, p.11) created by 
memoirists in dialogue with the interviewer (Moss and Mazikana 1986, p.25). The actuality, or audio recording, documents the lived-in experience of the data collection and requires little, if any, added detail to transmit the verisimilitude of the text.

Clifford Geertz has identified two problems associated with ethnographic research. The first problem he describes as the issue of being there (Geertz 1988, p.8). The ethnographic researcher is expected to produce a convincing amount of cultural detail to persuade the reader of the verisimilitude of his or her text. However, the researcher is also expected to preserve his or her objectivity, clearly distinguishing between being there and being separated from the phenomenon and thus objective (Goodenough 1970, pp.98-112). The second problem identified by Geertz (Geertz 1988, p.17) is the discourse problem: What is the work that the author authors? Roland Barthes tackles this issue by looking at the levels at which a text can be authored: as a constituent of a genre, as a device for understanding, as a determination of reality, or as a collection of the words of others (Barthes 1989, pp.56-64). Edward Bruner suggests all ethnographies are guided by implicit narrative structures (Bruner 1986, p.139) and consequently must be seen as merged subjective/objective interpretations of the dominant narrative structure of the time (Bruner 1986, pp.149-150). This article suggests that oral history is a particular form of ethnography that is well suited to resolving these important issues.

Much of the problem, described by Geertz as the issue of being there, is removed from the ethnographic process by the use of oral history evidence. The actuality provides an objective recording of the sounds of the time and place of the conversation between the memoirist and the interviewer. The richness of this conversation is preserved in the recording including the full vocal range of the memoirist and the subtle background audio environment or soundscape (Truax 1984, p.9) and thus represents a faithful document (Ridington 2001; Thompson 1988 p.108).

The discourse problem, identified by Geertz, is also reduced through the use of oral history evidence. It is important to recognize that the actuality represents discourse between its two authors: the interviewer and the memoirist. Life stories are derived from the perceptions of individuals (Thompson 1988, p.150), modified by their interpretation of these perceptions (Grele and Terkel 1985, p.133) after a period of reflection (Friedlander 1998, pp.314-318) and are presented in a form of narrative determined to be suited to the listener (Kopijin 1998, p.145). Whether oral histories are factual is not the central consideration. What is important is the "thick description" (Geertz 1973, p.6) of the memoirist's understanding of their entrepreneurial experience: their contemporary consciousness (Lummis 1987, p.133). In this light, the factors of lapsed time and modified perceptions increase the memoirist's understanding of the phenomenon in which he or she has participated (Hoopes 1979, p.47) and thus adds to the thickness of the description.

Two factors make life stories unique. First, life stories are not contemporaneous accounts of events; rather they represent the memoirist's attempt to recount events, as these events were perceived to have happened (Watson and WatsonFranke 1985, p.3). Thus, the story is not an account of events as they happened, but rather an attempt by the memoirist to make sense of his or her relationship to past events, often communicated in the form of a series of anecdotes centered on past events (Allen and Montell 1981, pp.28-29). Second, life histories are not self-initiated, but rather are discourses between the interviewer and the memoirist (Thompson 1988, p.199) and then between the actuality and the interpreter of the actuality (Dudley 1998, p.165). While the primary role of the interviewer is to act as a sounding board for the memoirist (Evans 1987, pp.26-27), an important secondary role for the interviewer is to act as the mediator who draws societal meaning out of the memoirist's internalized perception of events (Mintz 1996 pp.302-303). Thus, the memoirist claims authorship of his or her life history and the interviewer claims authorship of what Edward Bruner describes as "the three tellings of fieldwork" (Bruner 1986, p.147). The first of these tellings is the direction of the memoirist's recollection by telling what information the interviewer is seeking. The second telling is the part the interviewer plays in the creation of the actuality: both as a listener and as a questioner. The third telling is the summary and analysis the interviewer creates for the audience of his or her scholarly work.

The temporal and authorial flexibility of life histories make the medium well suited to the understanding of entrepreneurship (Phillips 1995). The process of new venture creation often does not conform to linear progression (Hansen and Bird 1997) and entrepreneurs often have to balance their perceptions of present and future (Eisenhardt and Brown 1998; Fischer et al. 1997). Similarly, the founding of a new venture is often shared by a network of founding figures (Aldrich and Zimmer 1986; Weinstein 1999). Joint authorship of organizational life histories help entrepreneurs to explain events without explicit agreement on criteria (Aldrich and Fiol 1994, p.652), develop a cohesive vision for action (Alvarez and Merchan 1992, p.40) and build organizational hegemony (Boje et al. 1999, p.358).

\section{Oral History Data \\ Selecting Memoirists}

Storytelling plays a vital role in the founding and building of a business (O'Connor 2002, p.39), and often reveals intimate details of both the venture's and the entrepreneur's life in a form that evokes the empathy of the listener (Steyaert and Bouwen 1997, p.47). The following transcription of a brief 
excerpt from an actuality exemplifies the intimate details that can be revealed in entrepreneur's oral histories:

It took me 15 years to build a company up to $\$ 30$ million or \$25 million or whatever it was and four days for it to crumble. And...ub...I moved to start again, and decided I would go into business again and I moved to Portland, Oregon, and did a consulting business and so forth; came up with this concept called Convergent Media Network, and I thought this was where the Internet was going to go and this is what's going to bappen there; but I really didn't have any energy to do anything to be bonest... and in...This may be more than you want to know about my personal life. On Thanksgiving in November my wife told me that she wanted me to leave and I found myself out without a family; without a business and the only thing that happened was that Christmas I got my kids and they have lived with me ever since (Vasko and McKenzie 2002).

The researcher who wants to employ oral history collection for entrepreneurship research must begin by building personal relationships with each of the entrepreneurs he or she wishes to interview. These personal relationships must be strong enough to warrant the trust as a confidant. To do this, the researcher must make his or her way into each entrepreneur's social network. An entrepreneur's social network can be modeled as a series of outwardly expanding rings of inti-

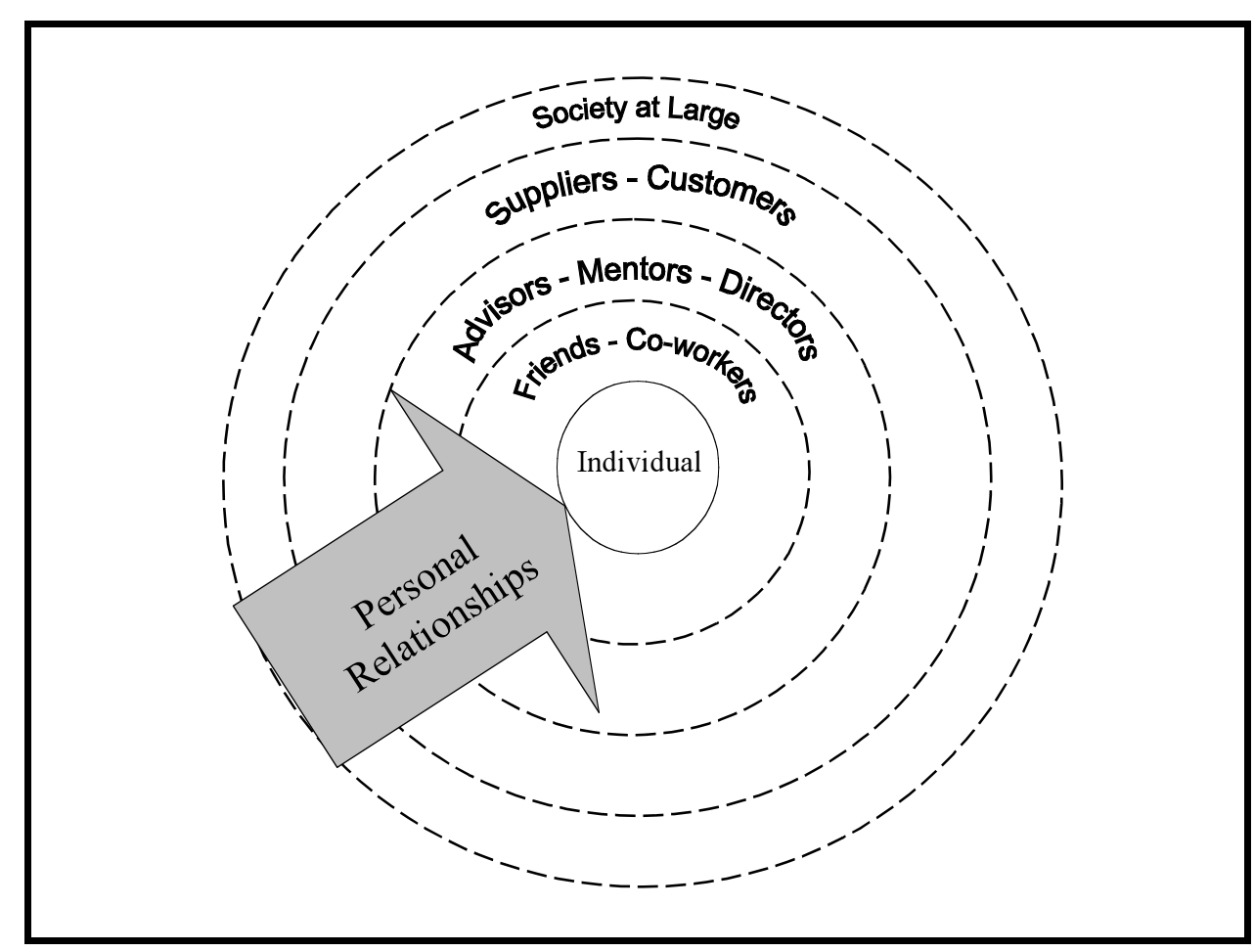

Figure 1. Model of an Entrepreneur's Social Network macy (Adler 1985, p.64) as shown in Figure 1.

The arrow in Figure 1 shows the researcher's starting position as a member of society at large. The arrow points out that the path toward a position of trust as a confidant means building personal relationships with advisors, mentors, or directors of the company or with the entrepreneur's friends or members of his or her organization. Many different personal relationships can be used to build a path toward a position of trust with the memoirists, including the interviewing friends or friends of friends, the receipt of introductions to entrepreneurs from trusted advisors or through networking agencies and meetings with entrepreneurs through social affinity.

Different research projects will require different selection criteria for memoirists. Some researchers will want to develop intensive interviews of particular industry or social networks. An example of this kind of research is shown in Mina Yoo's qualitative interviews with immigrant and native-born Americans operating in high-technology industries in Silicon Valley (Yoo 2004). Other researchers might take a more open approach in an attempt to develop a theoretical or random sample. Dorothy and David Counts took such an approach in their ethnographic fieldwork exploring the values of seniors who live in recreational vehicles (Counts and Counts 2001). Whichever approach is taken, researchers will find that oral histories provide a rich and relatively bias-free source of unstructured data.

\section{Data Quality}

Within positivistic research, data quality is usually measured in terms of validity and reliability. In interpretive research such as ethnographic studies, data quality relies on the relationship between the researcher and his or her audience (Goldenberg 1992, p.111). Validity, within positivistic research, is defined as a measurement of the accuracy of information and its generalizability (Creswell 1994, p.158). In qualitative research, the construct of validity is generalized to truthfulness of investigation (Kvale 1995, p.25). Reliability, within positivistic research, has been defined as a measurement of the likelihood of similar conditions giving rise to similar observations (Aunger 1995, p.99). In qualitative research, the construct of reliability is generalized to craftsmanship on the part of the researcher. Craftsmanship in research embraces rigorous techniques of research design, data collection, inter- 
pretation of data, and communication of results (Mays and Pope 1995, p.110).

Validity can be broken down into two constructs: internal validity, which concerns the accuracy of information and external validity, which concerns the generalizability of findings. The construct of internal validity in positivist science corresponds to veracity or the degree of correspondence with objective (Kvale 1995, p.23). Postmodern philosophy of science disputes the notion of objective reality (Feyerabend 1975, pp.81-92) and substitutes "spirit of truth" (Ricoeur 1965, pp.189-190) as the measurement of veracity. Veracity can be tested by comparing the events described in the actuality for conformity with printed records (Allen and Montell 1981, p.85). The construct of external validity in positivist science corresponds to generalizability and is generally treated as a sampling issue in interpretive inquiry (Zikmund 1994, p.259). Sheldon Goldberg has argued that the external validity of a study is a combination of the techniques used in establishing a representative sampling and the negotiation between the researcher and the audience of the limits of the generalizability of the findings of the study (Goldenberg 1992, pp.97-98).

Evidentiary reliability is an evaluation of the internal consistency of the memoirist's narrative (Lummis 1987, p.83). While remembering that it is the sense-making of the memoirist's relationship to past that is being recorded, each actuality can be tested for reliability by ensuring the story has coherence, consistence, and is free of contradictions (Fisher 1985 p.364). Reliability in the interpretation of actualities can be much more difficult to establish. Care should be taken in the documentation and the referencing of the interpretation process to ensure that a clear trail of the researcher's work has been left. The design of the documentation of this trail is laid out in the following discussion of protocols suggested for oral history collection.

\section{Protocols for Oral History Collection}

The protocols outlined in this section are intended to ensure the authenticity of data collection and replication. In all cases, the actuality recorded with the memoirist is to be considered the document of reference. Current best practices in oral history collection suggest that transcriptions only be made of sections referred to in the documentation and interpretation of the interviews. These transcriptions must be made accurately and without editing grammar or syntax (Davis et al. 1977, p.48-49).

\section{Autborship}

In all cases, the interviewer is considered the primary author of the interview, while the memoirist is considered the author of his or her actual words (Thompson 1988, p.224). Copyright for the recording is held by the inter- viewer, retaining the rights to publish the recording for the first time, to reproduce the recording in any material form, to rent it out, and to authorize any such acts (U.S. Government, 2002, Chapter 2, Section 201). However, any royalties received from the recording should be split equally between the interviewer and the memoirist of that recording (U.S. Government, 2002, Chapter 10 Subchapter C, Section 1007).

\section{Recording}

The current standard device used in oral history recording is the mini-disc portable recorder coupled with a one point stereo microphone. However, technological development of portable recording devices is providing oral history researchers with increasingly sophisticated field equipment. The primary concern of researchers in evaluating field equipment should be recording quality. The microphone and recorder should be capable of accurately capturing frequencies between 100 and 15,000 hertz. Secondary concerns for the evaluation of recording equipment include field ruggedness, ease of use, size, and storage capacity. Researchers should also consider the compatibility of their field equipment with standard desktop and laptop hardware and software. Video recording equipment offers a paradox to the oral historian. While the capture of image and sound should afford increased realism of the memoirist's interview, production difficulties associated with video tend to create a distraction from the easy flow of conversation. Each researcher will have to determine the costs and benefits of video capture as a part of his or her style of interviewing.

\section{Documentation}

An oral note of the date, location, and memoirist recorded in each session should be made at the beginning of each recording disc. If the session extended beyond the length of a single disc, subsequent discs should be labeled as soon after the session as is feasible.

Immediately after each session, it is good practice to activate the play-only tab on the mini-disc to protect the disc from erasure. As soon after the interview as feasible, a master original should be copied from the actuality and an outline created.A complimentary copy can be made from the master original and sent to the memoirist along with a letter of thanks. The original recording should then be placed in a safety deposit box and the master original should be placed in a fireproof storage box. The medium, storage, and access restrictions of each copy of the interviews collected have been summarized in Table 1.

It is good practice to create an outline of each recording as a text document, which contains a summary of the memoirist's conversation. The outlines can be kept as a separate 
Table 1. Summary of Storage and Access to Recordings

\begin{tabular}{|c|c|c|c|}
\hline Description & Medium & Storage & Access \\
\hline Original recording & $\begin{array}{l}\text { Sony MDW74D } \\
\text { recordable magneto- } \\
\text { optical disc }\end{array}$ & Safety deposit box & $\begin{array}{l}\text { Principal researcher } \\
\text { only to create } \\
\text { master original }\end{array}$ \\
\hline Master original & $\begin{array}{l}\text { HHB brand CDR } 74 \\
\text { gold or silver } \\
\text { recordable compact } \\
\text { disc }\end{array}$ & $\begin{array}{l}\text { Locked fireproof } \\
\text { box in different } \\
\text { location from } \\
\text { original recording }\end{array}$ & $\begin{array}{l}\text { Principal researcher } \\
\text { only to create } \\
\text { working copies }\end{array}$ \\
\hline $\begin{array}{l}\text { Working copy } \\
\text { (number) }\end{array}$ & $\begin{array}{l}\text { Generic CDR } 74 \\
\text { recordable compact } \\
\text { disc }\end{array}$ & $\begin{array}{l}\text { Locked filing cabinet } \\
\text { at principal } \\
\text { researcher's work } \\
\text { station }\end{array}$ & $\begin{array}{l}\text { Principal researcher } \\
\text { and others with } \\
\text { specific permission }\end{array}$ \\
\hline $\begin{array}{l}\text { Complimentary } \\
\text { copy }\end{array}$ & $\begin{array}{l}\text { Generic CDR } 74 \\
\text { recordable compact } \\
\text { disc }\end{array}$ & $\begin{array}{l}\text { Delivered to } \\
\text { memoirist }\end{array}$ & Memoirist \\
\hline MP3 Copy & $\begin{array}{l}\text { Generic CDR } 74 \\
\text { recordable compact } \\
\text { disc }\end{array}$ & $\begin{array}{l}\text { Locked filing cabinet } \\
\text { at principal } \\
\text { researcher's work } \\
\text { station and } \\
\text { computer hard drive }\end{array}$ & General \\
\hline
\end{tabular}

document filed with the memoirist's first and last names. These outlines should contain a summary of the conversation at each two-minute mark in time (Hitch and Norris 1988, p.26; McCracken et al. 1974, p.11). General information, including the memoirist's contact information can be stored in a recording catalog. This catalog can be created using database software in a format designed to be compatible with standard archival document retrievals system standards (Langlois 1976, p.24).

A separate physical file should be kept for each interview. This file can contain copies of correspondence between the interviewer and memoirist, the signed Participant Consent form, a paper copy of the recording outline and a working copy of the interview, as well as any previous or subsequent documentation of the memoirist and his or her ventures. These files should be kept in a locked cabinet at the principal researcher's workstation. A working copy of the recording catalog should be stored on the principal researcher's computer; a backup copy kept in the locked fireproof box with the master original recordings.

\section{Transcription}

A transcription is a text version of what has been said (Taylor 2001, p.36). Paul Thompson has pointed out that transcription is a literary form requiring interpretation of the grammar and phrasing of an oral document (Thompson 1988, pp.229-232). Accurate transcription takes between six and eight hours of work for each hour of interview (Ritchie 2003, p.65). In many history collections, the actuality recorded with the memoirist is considered the document of reference (Atkinson 1998, p.54). There is no necessity, therefore for researchers to attempt the difficult and time-consuming and costly task of transcribing interviews in their entirety. The outline of each recording can act as a reference to direct the researcher to specific parts of the interview.

Transcription of entire interviews served as a ready means of data transfer when print was the primary form of communication in the academic community. However, recent developments in electronic technology have allowed scholars to accurately and inexpensively transfer audio documents via the Internet and lightweight compact discs. Interestingly, dif- 
ferent cultures regard different media as the primary research tool. Canadian oral historians have adopted "aural history" (Langlois 1976, p.24) and thus regard the sound archive as the document of reference. American researchers tend to treat the transcript as the primary research tool (Ritchie 2003, p.87). Differing disciplines tend to have differing bias toward the use of audio or text as the primary research tool (Yow 1994, p.227). It would appear that, since business management is primarily a culture that has a strong preference for verbal communication (Mintzberg 1971, p.39) it would be appropriate for management researchers to use audio recordings as their primary research tool.

Audio documents contain more data than written transcriptions. Thompson summarizes the case for audio documents in this way:

...the recording is a far more reliable and accurate account of an encounter than a purely written record. All the exact words used are there as they were spoken' and added to them are social clues, the nuances of uncertainty, bumor or pretence as well as the texture of dialect (Thompson 1988, p.108).

Seal and Silverman have demonstrated how incomplete transcription can obscure the researcher's full understanding of a conversation (Seale and Silverman 1997). The flatness of transcription compared to the richness of audio can be imagined by the reader of the following of a piece of an interview:

And I finally said to the guy we were dealing with, "If you think for one moment, that I'm going to let you bave the source code; I said you're nuts. I will tear this company down. I will fold this company before I will ever, ever give you the source code. I will fight this in court to my last breath. Don't mess with me on this one." And that was the last guy... and they dropped it (Stephens \& McKenzie, 2002).

Missing from the transcription is the power of the voice of this female entrepreneur as she recounts one of the most important battles of her career. The reader cannot build into the reading of this transcription the memoirist's sense of frustration and determination. However, the audio recording captures her emotion in the tonality and phrasing of her words. A summary of the relative benefits of oral recording and text transcriptions as primary research document is provided in Table 2 .

Transcription of portions of recorded interviews is a necessary part of interpretation. When capturing the text of portions of an interview for inclusion in an article, the researcher may find transcription software an asset. Express Scribe Transcription Playback Software (ExpressScribe 2002) produced by NCH Swift Sound is an excellent freeware aid to accurate transcription. Express Scribe Transcription Playback Software allows the transcriber to slow down the playback of recordings to an appropriate speed for accurate transcription. The software uses the function keys of a standard computer keyboard to control the playback of a recording. This facilitates the transcriber's ability to stop, rewind, and manipulate the speed of the recording without having to remove his or her fingers from the keyboard.

\begin{tabular}{|l|ll|}
\hline \multicolumn{3}{|c|}{ Table 2. Comparison of Audio Recording and Text Transcription } \\
\hline Authenticity & \multicolumn{1}{|c|}{ Audio Recording } & \multicolumn{1}{c|}{ Text Transcription } \\
\hline Cost & $\begin{array}{l}\text { Fidelity of the sound of } \\
\text { original conversation } \\
\text { Rata richness }\end{array}$ & $\begin{array}{l}\text { Mediated reproduction of text } \\
\text { of original conversation }\end{array}$ \\
& $\begin{array}{l}\text { Reproduction of words, } \\
\text { grammar, phrasing, tonality, } \\
\text { and soundscape of original } \\
\text { conversation }\end{array}$ & $\begin{array}{l}\text { Interpretation of words and } \\
\text { grammar of original }\end{array}$ \\
conversation \\
Distribution & $\begin{array}{l}\text { Audio files via Internet or } \\
\text { audio compact disc }\end{array}$ & $\begin{array}{l}\text { Text files via Internet or } \\
\text { printed paper }\end{array}$ \\
Ease of Analysis & $\begin{array}{l}\text { Two-step process utilizing } \\
\text { outline and audio recording }\end{array}$ & $\begin{array}{l}\text { Analysis can be performed } \\
\text { directly from digital or paper } \\
\text { text }\end{array}$ \\
\hline
\end{tabular}




\section{Editing}

Accuracy is the central goal of editing oral history recordings (Wilmsen 2001, p.65). The accuracy of the actuality can be diminished through poor recording quality, misstatement by the memoirist, or misrepresentation of the discourse of the interview process. Any decisions to edit an interview should be made only after discussion with the memoirist or when the memoirist specifically has asked that comments made during an interview be kept off the record. Damaged or excess compact discs should be destroyed according to current best practices: placing each disc to be destroyed on a nonmetallic stand in a microwave oven and subjecting it to 15 seconds of high temperature radiation (Ardant 2000).

\section{Preservation and Archiving}

Security of data can best be ensured through a strategy of distributed storage. This strategy is based on data being stored in multiple media formats in multiple locations. As soon as possible after the recording session, the data should be transferred to an archival compact disc. It is suggested that audio editor software such as Goldwave Digital Audio Editor software (Goldwave Inc. 2003) be used to convert the signal to WAVE format in 16 bit stereo mode at a sampling rate of 44100 hertz. The resulting file should be recorded on an $\mathrm{HHB}$ brand Compact Disc Recordable (CDR) 74 gold or silver recordable compact disc using compact disc creation software such as Roxio Easy CD Creator software (Roxio 2004). HHB CDR 74 gold or silver recordable compact discs have archival stability estimated to be in excess of 100 years. This disc will act as the "master original." Two other compact disc copies should also be made at this time, using any available brand of CDR disc. These discs will act as the "working copy," and the "complimentary copy." A second working copy of each interview can be created from the master original in MP3 format using software such as Thompson MP3PRO Player/Encoder (Thompson 2004). Encoding interviews into MP3 format allowed all data collected to be stored on one compact disc and on the hard drives of multiple computers to further distribute the data.

All labels must be of archival quality to prevent diminishment of the archival stability of the compact disc. The original recordings should be used only in the creation of the master originals (Langlois 1974, p.28).All master originals should be stored together in a locked fireproof box (UL rating 3501/2hr) kept in an environment with a low, constant temperature (8 C - $18 \mathrm{C}$ ) and constant humidity (40\%) (Linstead 2001). The master originals are intended for use only in the creation of the working copies.

\section{Ethical Considerations}

The cardinal principle of research ethics is respect for human dignity (Medical Research Council et al. 1998, i.5).The spoken word is open to interpretation (Borland 1996), which can lead to harm of the interview participants. While no more information is expected from the research subjects than what he or she would reveal in the normal course of everyday life, some memoirists may make libelous, slanderous, or defamatory remarks during their interviews, as they would be in the normal course of their everyday life (Moss 1974, p.15). Prior to each recording, the interviewer should inform the interviewee of his or her responsibility in terms of libelous, slanderous, or defamatory material. At all times during the interview, the importance of gaining understanding of the process of entrepreneurship must be balanced against the potential for harm.

The memoirists who participate in oral history studies can reasonably expect minimal risk of harm resulting from their participation. Minimum risk of harm is defined as:

...the probability and magnitude of possible

harms implied by participation in the research project will be no greater than those encountered by the subject in those aspects of his or her everyday life that relate to the research (Medical Research Council et al. 1998, 1.5).

All subjects participating in oral history interviews must do so with free and informed consent. Prior to each interview, the researcher should review and have the memoirist approve a Participant Consent form. While the particulars of such a form will be negotiated with the Human Subjects Research Ethics Committee at the researcher's institution, the following topics are suggested as guidelines:

1. Contact information for the researcher and for the researcher's institution should be given.

2. The nature of the research and if possible specific research questions should be generally explained.

3. Each participant should be informed that he or she can withdraw from the research project at any time without any consequences or any explanation.

4. It should be explained to each participant that he or she will receive a complimentary compact disc copy of the actuality produced with him or her. Each memoirist should be asked to review this complimentary copy to ensure that there was no material that he or she feels should be kept "off the record."

5. If there is controversial material in the recording, the researcher should agree in advance that he or she will edit the offending material.

6. Copyright and royalty splitting should be clearly stated.

7.The memoirist should consent to the donation of the recording to a recognized oral history program. This donation should be granted on a standard Tape Release form used by that institution. In every case, each participant should be asked to sign a copy of the Participant Consent form and the Tape Release form before the 
interview process begins. Questions from any participant about the research project should be dealt with openly and honestly prior to his or her commitment to participate. A sample Participant Consent form is pre- sented in Figure 2. This Participant Consent form has been accepted by the Human Subjects Research Ethics Committees at two universities.

You are being invited to participate in a study entitled that is being conducted by (Researcher name). (Researcher name) is a/n (Researcher title) at (Researcher institution) and you may contact him/her if you have further questions by phoning (Researcher phone number) or by e-mail: (Researcher e-mail).

The purpose of this research project is (Specify research goals)

Research of this type is important because (Specify importance). It is hoped this research project will contribute to the field of entrepreneurship research by (specify contribution). The collection of oral histories of entrepreneurs is intended to become an ongoing source of information for entrepreneurship researchers.

You are being asked to participate in this study because you have been identified as an entrepreneur through published description, receipt of nomination/award for entrepreneurial achievement or credible third party reference.

If you agree to voluntarily participate in this research, your participation will include being asked to tell your life history.

The potential benefits of your participation in this research include having your life story recorded and receiving a copy of this recording. Society will benefit from this unique collection of oral histories, since oral history collections have become an important source of historical and cultural data. It is expected that this particular collection of oral histories will contribute significantly to the knowledge of entrepreneurial decision-making and communication.

Your participation in this research must be completely voluntary. If you do decide to participate, you may withdraw at any time without any consequences or any explanation. If you do withdraw from the study your data will be destroyed.

This research may lead to a commercial product or service. The nature of this commercial use is publication of the study, which may include publication of part of the recording of your entire interview. I will hold copyright for the recording and will retain the rights to publish the recording for the first time, to reproduce the recording in any material form, to rent it out, and to authorize any such acts. You will have the right to use the recording for your own purposes. Any royalties received from a particular interview will be split equally between the principal researcher and the interviewee in accordance with the US Copyright Law.

Since you are being asked to record your oral history, any quotations or your remarks will be attributed to you, and no effort will be made to protect your anonymity in this study. The oral history that you are being asked to provide will be a public document. You will be given a copy of the interview for review. Any material, which you deem might be harmful, will be deleted from the original recording, and a revised recording will be made. Otherwise, no attempt will be made to provide confidentiality of the information that you have recorded.

The data collected in this study is intended to form the basis for a public collection of oral histories. It is likely that these oral histories may be used in subsequent research. When this particular research project is complete, the recordings will be donated to a suitable recording library.

I am anticipating that the results of this study will be shared with others through presentation at scholarly meetings. It is also possible that the results may be published in articles or books.

In addition to being able to contact the researcher at the above phone numbers, you may verify the ethical approval of this study, or raise any concerns you might have, by contacting (Name and phone number of contact at Institutional Review Board).

Your signature below indicates that you understand the above conditions of participation in this study and that you have had the opportunity to have your questions answered by the researcher.
Name of Participant
Signature
Date

A copy of this consent will be left with you, and a copy will be taken by the researcher.

Figure 2. Example of Participant Consent Form 


\section{Summary}

Oral history collection promises a new source of high-quality data for entrepreneurship study. This article has shown that the employment of a simple set of protocols can lead to the gathering of data describing entrepreneurs' work experience.

Oral history collection can be used as fieldwork projects for students of entrepreneurship. Student oral history projects, such as the Foxfire Project (Wigginton 1998), have shown how the experience of oral history collection can lead to the transfer of tacit knowledge. Jeffry Timmons suggests directed interviews of entrepreneurs as an integral part of his entrepreneurship curriculum (Timmons 1999). Instructors can utilize information from oral history collection to add the excitement and interest of the field to class- room discussion. Audio clips of the experiences of working entrepreneurs can dramatize and engage student interest in theoretical concepts.

Oral history collection shows promise of providing a wealth of detailed information for entrepreneurship researchers. The stories that entrepreneurs tell provide researchers with insight into both perspective and into substantive issues of entrepreneurial behavior.

The life stories of entrepreneurs offer students of entrepreneurship insight into both the explicit and the tacit knowledge of working entrepreneurs. This article has outlined the importance of this field knowledge to the study of entrepreneurship. Adoption of the protocols laid out in this research can lead both educators and researchers toward a valuable new source of high-quality data.

\section{References}

Adler, P.A. 1985. Wheeling and dealing:An ethnography of an upper-level drug dealing and smuggling community. New York, NY: Columbia University Press.

Aldrich, H., and C. Zimmer. 1986. Entrepreneurship through social networks. In S. D. R. Smilor, ed., The art and science of entrepreneurship. Cambridge, MA: Ballinger.

Aldrich, H. E., and T. Baker. 1997. Blinded by the cites? Has there been progress in entrepreneurship research? In D. L. Sexton and R. W. Smilor, eds., Entrepreneurship 2000. Chicago, IL: Upstart Publishing Company, pp. 377-400.

Aldrich, H. E., and C. M. Fiol. 1994. Fools rush in? The institutional context of industry creation. The Academy of Management Review 19, 4: 645-670.

Allen, B., and W. L. Montell. 1981. From memory to history: Using oral sources in local historical research. Nashville,TN: American Association for State and Local History.

Alvarez, J. L., and C. Merchan. 1992. The role of narrative fiction in the development of imagination for action. International Studies of Management \& Organization 22,3.

Ardant, D. 2000. The toasties nuke guide. Retrieved Dec. 6, 2001, 2001, from http://toast.ardant.net/guide.shtml.

Atkinson, R. 1998. The life story interview. Thousand Oaks, CA: Sage Publications.

Aunger, R. 1995. On ethnography: Storytelling or science? Current Anthropology 36, 1: 97-130.

Barthes, R. 1989. The rustle of language. Berkeley, CA: University of California Press.

Barton, C. 1998. Howard Hughes and his flying boat. Vienna, VA: Charles A. Barton, Inc.

Berlin, L. 2005. The man behind the microchip: Robert Noyce and the invention of Silicon Valley. New York, NY: Oxford University Press.

Boje, D. M. 1991. The storytelling organization:A study of story performance in an office supply firm. Administrative Science Quarterly 36, 1: 106-126.

Boje, D. M., J.T. Luhman, and D. E. Baack. 1999. Hegemonic stories and encounters between storytelling organizations. Journal of Management Inquiry 8, 4: 340-360.

Borland, K. 1996. "That's not what I said": Interpretive conflict in oral narrative research. In D. K. Dunaway and W. K. Baum, eds., Oral history:An interdisciplinary anthology, 2nd ed. Walnut Creek, CA:AltaMira Press, pp. 320-332.

Bruner, E. M. 1986. Ethnography as narrative. In V.W.Turner and E. M. Bruner, eds., The anthropology of experience (pp. 139-155). Urbana, IL: University of Illinois Press.

Chetty, S. 1996. The case study method for research in small-and medium-sized firms. International Small Business Journal 15: 1:73-85.

Counts, D.A., and D. R. Counts. 2001. Over the next hill:An ethnography of "RVing seniors" in North America, 2 nd. ed.. Peterborough, ON: Broadview Press. 
Creswell, J. 1994. Research design: Qualitative \& quantitative approaches. Thousand Oaks, CA: Sage Publications.

Davis, C., K. Back, and K. MacLean. 1977. Oral history: From tape to type. Chicago, IL:American Library Association.

Dudley, K. M. 1998. In the archive, in the field:What kind of document is an "oral history." In M. Chamberlain and P. R.

Thompson, eds., Narrative and genre. London UK: Routledge, 160-166.

Eisenhardt, K. M. 1989. Building theories from case study research. The Academy of Management Review 14, 4:532-551.

Eisenhardt, K. M., and S. L. Brown. 1998. Time pacing: Competing in markets that won't stand still. Harvard Business Review (March-April), 59-69.

Emerson, R. M., R. I. Fretz, and L. L. Shaw. 1995. Writing ethnographic fieldnotes. Chicago, IL: University of Chicago Press.

Evans, G. E. 1987. Spoken history. London, UK: Faber.

ExpressScribe. 2002. Express scribe transcription playback software (Version 3.04) [transcription software]. Canberra,ACT:

NCH Swift Sound.

Feyerabend, P. K. 1975. Against method, 1978 ed. London, UK: Verso.

Fischer, E.,A. R. Reuber, M. Hababou, W. Johnson, and S. Lee. 1997. The role of socially constructed temporal perspectives in the emergence of rapid-growth firms. Entrepreneurship Theory and Practice 22, 2: 13-30.

Fisher,W. R. 1985. The narrative paradigm:An elaboration. Communication Monographs 52:347-367.

Friedlander, P. 1998. Theory, method and oral history. In R. Perks and A.Thomson, eds., The oral history reader. London, UK: Routledge, 311-319.

Frolick, V. 1999. Fire into ice: Charles Fipke and the great diamond hunt. Vancouver, BC: Raincoast Books.

Gates, B., and C. Hemingway. 1999. Business @ the speed of thought: Using a digital nervous system. New York, NY:Warner Books.

Geertz, C. 1973. The interpretation of cultures: Selected essays. New York, NY: Basic Books.

Geertz, C. 1988. Works and lives: The anthropologist as author. Stanford, CA: Stanford University Press.

Goldenberg, S. 1992. Thinking methodologically. New York, NY: HarperCollins.

Goldwave Inc. 2003. Goldwave digital audio editor (Version 4.26) [Audio Editor Software]. St. John's, NFLD: GoldWave Inc.

Goodenough,W. H. 1970. Description and comparison in cultural anthropology. Chicago, IL:Aldine Pub. Co.

Grele, R. J., and S.Terkel. 1985. Envelopes of sound:The art of oral history, 2nd revised ed. Chicago, IL: Precedent Publishing Inc.

Hansen, E. L., and B. J. Bird. 1997. The stages model of high-tech venture founding:Tried but true? Entrepreneurship Theory and Practice 22, 2: 111-122.

Henige, D. P. 1982. Oral historiography. New York, NY: Longman.

Hitch, C., and J. Norris. 1988. Conducting an oral history interview. Willowdale, ON: Ontario Historical Society.

Hoopes, J. 1979. Oral history: An introduction for students. Chapel Hill, NC: University of North Carolina Press.

Kanter, R. M. 1983. The change masters: Innovation \& entrepreneurship in the American corporation. New York, NY: Simon and Schuster.

Kaplan, D.A. 2000. The silicon boys and their valley of dreams (First Perennial Edition ed.). New York, NY: HarperCollins Publishers Inc.

Kopijin, Y. J. 1998. The oral history interview in a cross-cultural setting:An analysis of its linguistic, social and ideological structure. In M. Chamberlain and P. R. Thompson, eds., Narrative and genre. London UK: Routledge, 142-159.

Kvale, S. 1995. The social construction of validity. Qualitative Inquiry 1, 1: 19-41.

Kvale, S. 1996. Interviews: An introduction to qualitative research interviewing. Thousand Oaks, CA: Sage Publications.

Langlois, W. J. 1974. Aural History Institute of British Columbia manual. Victoria, BC:Aural History Institute of British Columbia.

Langlois, W. J. 1976. A guide to aural history research. Victoria, BC:Aural History Provincial Archives of British Columbia.

Linstead, C. 2001. Preserving digital sound recordings. 
Low, M. B., and I. C. MacMillan. 1988. Entrepreneurship: Past research and future challenges. Journal of Management 14, 2: 139-161.

Lummis, T. 1987. Listening to bistory: The autbenticity of oral evidence. London, UK: Hutchinson Education.

Mays, N., and C. Pope. 1995. Rigour and qualitative research. British Medical Journal 311, 6997: 109-113.

McCracken, J. W., E. Bronstein, D. Jenkins, and M. Quesnel. 1974. Oral bistory: Basic techniques. Winnipeg, MAN: Manitoba Museum of Man and Nature.

McKenzie, B. 2003. Understanding entrepreneurship: A definition and model based on economic activity and the pursuit of self-identity. Unpublished Dissertation, University of Victoria, Victoria, B.C.

Medical Research Council, Natural Sciences and Engineering Research Council, \& Social Sciences and Humanities Research Council. 1998. Tri-council policy statement: Ethical conduct for research involving humans (Policy Statement).

Mintz, S. 1996. The anthropological interview and the life history. In D. K. Dunaway and W. K. Baum, eds., Oral bistory:An interdisciplinary antbology, 2nd ed. Walnut Creek, CA:AltaMira Press, 298-305.

Mintzberg, H. 1971. Managerial work:Analysis from observation. Management Science 18: 97-110.

Moss, W.W. 1974. Oral bistory program manual. New York, NY: Praeger.

Moss, W.W., and P. C. Mazikana. 1986. Archives, oral bistory, and oral tradition:A ramp study. Paris, France: General Information Programme and UNISIST United Nations Educational Scientific and Cultural Organization.

Nevins, A. 1996. Oral history: How and why it was born. In D. K. Dunaway and W. K. Baum, eds., Oral bistory: An interdisciplinary anthology (2nd ed., pp. 29-38). Walnut Creek, CA:AltaMira Press.

O'Connor, E. 2002. Storied business:Typology, intertextuality, and traffic in entrepreneurial narrative. The Journal of Business Communication 39 1:36-54.

Phillips, N. 1995. Telling organizational tales: On the role of narrative fiction in the study of organizations. Organization Studies 16, 4: 625.

Ricoeur, P. 1965. History and truth. Evanston IL: Northwestern University Press.

Ridington, R. 2001. Oral bistory practice (an overview). Unpublished evaluation, University of British Columbia, Vancouver, BC.

Ritchie, D.A. 2003. Doing oral bistory, 2nd ed. New York, NY: Oxford University Press.

Rosenberg, N.V. 1978. Folklore and oral bistory. Paper presented at the Second Annual Meeting of the Canadian Aural/Oral History Association, St. John's NFLD.

Rothchild, J. 1991. Going for broke: How Robert Campeau bankrupted the retail industry and brought the booming eighties to a crashing balt. New York, NY: Simon and Schuster.

Roxio. 2004. Roxio easy CD creator (Version 5.3.5). Santa Clara, CA: Roxio Corporation.

Seale, C., and D. Silverman. 1997. Ensuring rigour in qualitative research. The European Journal of Public Healtb 7 , 4: 379-384.

Starr, L. 1996. Oral history. In D. K. Dunaway and W. K. Baum, eds., Oral bistory: An interdisciplinary anthology, 2nd ed. Walnut Creek, CA:AltaMira Press, pp. 39-61.

Stephens, C., \& McKenzie, B. (2002). Chris Stephens oral history [Audio recording]. Sidney, BC.

Stewart,A. 1991.A prospectus on the anthropology of entrepreneurship. Entrepreneurship:Theory and Practice 16, 2.

Stewart, A. 2003. Help one another, use one another:Toward an anthropology of family business. Entrepreneurship:Theory and Practice 27, 4: 383-397.

Steyaert, C. 1995. Perpetuating entrepreneurship through dialogue. A social constructionist view. Unpublished Ph.D. Dissertation, Leuven.

Steyaert, C., and R. Bouwen. 1997. Telling stories of entrepreneurship - towards a narrative-contextual epistemology for entrepreneurial studies. In R. Donckels and A. Mietten, eds., Entrepreneurship and SME research: On its way to the next millenium. Aldershot, UK:Ashgate Publishing, pp. 47-62.

Taylor, S. 2001. Locating and conducting discourse analytic research. In M. Wetherell, S. Taylor, and J.Yates, eds., Discourse as data: A guide for analysis. London, UK: Sage Publications Ltd., pp. 338. 
Thompson. 2004. Thompson mp3 pro audio player (Version 1.1.0) [MP3 converter]. Boulogne Cedex, France: Coding Technologies.

Thompson, P. R. 1988. The voice of the past: Oral history, 2nd ed. Oxford UK: Oxford University Press.

Timmons, J.A. 1999. New venture creation: Entrepreneurship for the 21st century, 5th ed. Burr Ridge, IL: Irwin.

Truax, B. 1984. Acoustic communication, 2nd ed. Norwood, N.J.:Ablex Pub. Corp.

U. S. Government. 2002. Copyright law of the United States of America. Washington D.C.: U.S. Copyright Office.

Vasko, T., and B. McKenzie. 2002.Tim Vasko oral history [Audio recording]. Sidney, BC.

Watson, L. C., and M.-B Watson-Franke. 1985. Interpreting life histories: An anthropological inquiry. New Brunswick, NJ: Rutgers University Press.

Weinstein, M. 1999. Railbirds, scouts, and independent booksellers:Towards a constructivist interpretation of new business formation. Irish Marketing Review 12, 1:3-16.

Wigginton, E. 1998. Reaching across the generations:The foxfire experience. In R. Perks and A.Thomson, eds., The oral bistory reader. London, UK: Routledge, pp. 206-213.

Wilmsen, C. 2001. For the record: Editing and the production of meaning in oral history. Oral History Review 28, 1: 65-86.

Yoo, M. 2004. Ties that (un)bind: Interpersonal networks and early-stage performance among Silicon Valley entrepreneurs. Paper presented at the Babson Kauffman Entrepreneurship Research Conference, Glasgow, Scotland.

Yow, V. R. 1994. Recording oral history: A practical guide for social scientists. Thousand Oaks, CA: Sage Publications.

Zikmund, W. G. 1994. Business research methods, 4th ed. Orlando, FL: Harcourt Brace College Publishers.

About the Author

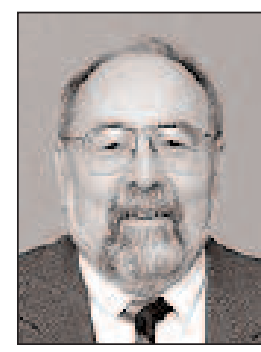

BRIAN MCKENZIE (brian.mckenzie@csueastbay.edu) is an assistant professor of entrepreneurship at California State University, East Bay. His research and teaching draw heavily on his 30 years as a successful entrepreneur and small business manager.

Prof. McKenzie received his B.A. from the University of British Columbia in 1974, his MBA from the University of Victoria in 1997 and his Ph.D. from the University of Victoria in 2003.

He has been awarded the 1999 AOM Entrepreneurship Division Innovations in Pedagogy Award, the 2000 USASBE Model Undergraduate Program Award, and the 2004 Entrepreneurship Theory and Practice Best Conceptual Paper Award. 